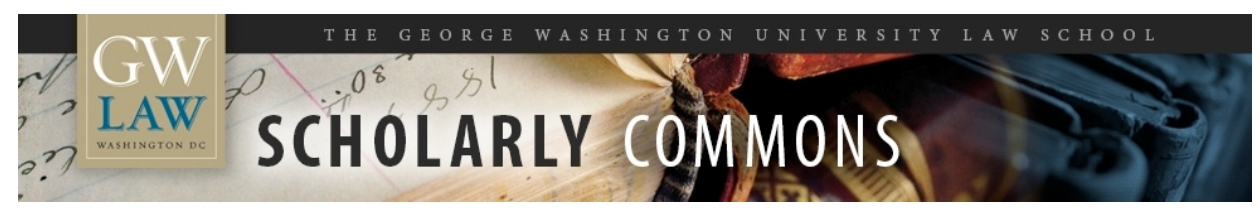

GW Law Faculty Publications \& Other Works

Faculty Scholarship

2017

\title{
The Evolution of Global Legal Pluralism
}

Paul Schiff Berman

George Washington University Law School, pberman@law.gwu.edu

Follow this and additional works at: https://scholarship.law.gwu.edu/faculty_publications

Part of the Law Commons

\section{Recommended Citation}

Berman, Paul Schiff, The Evolution of Global Legal Pluralism (2017). GWU Law School Public Law Research Paper No. 2017-42; The Evolution of Global Legal Pluralism, in Authority in Transnational Legal Theory: Theorising Across Disciplines 151 (Roger Cotterrell \& Maksymilian Del Mar eds., 2016).; GWU Law School Public Law Research Paper No. 2017-42; GWU Legal Studies Research Paper No. 2017-42. Available at SSRN: https://ssrn.com/abstract=

This Article is brought to you for free and open access by the Faculty Scholarship at Scholarly Commons. It has been accepted for inclusion in GW Law Faculty Publications \& Other Works by an authorized administrator of Scholarly Commons. For more information, please contact spagel@law.gwu.edu. 


\section{The evolution of global legal pluralism}

\section{Paul Schiff Berman*}

Global legal pluralism is now recognized as an entrenched reality of the international and transnational legal order. Indeed, wherever one looks, there is conflict among multiple legal regimes. Some of these regimes are state-based, some are built and maintained by non-state actors, some fall within the purview of local authorities and jurisdictional entities, and some involve international courts, tribunals, arbitral bodies, and regulatory organizations. ${ }^{1}$

It has now been approximately 20 years since scholars first began pushing the insights of legal pluralism into the transnational and international arena. During those two decades, a rich body of work has established pluralism as a useful descriptive and normative framework for understanding a world of overlapping jurisdictional assertions, both state and non-state. Indeed, there has been a veritable explosion of scholarly work on legal pluralism, soft law, global constitutionalism, the relationships among relative authorities, and the fragmentation and reinforcement of territorial boundaries.

Thus, the time has come for a survey and analysis of this literature in order to understand the evolution of global legal pluralism as a scholarly trope. In this chapter, I seek to begin such a task by separating out some of the descriptive and normative strands in the scholarly discourse. In addition, I tackle challenges and criticisms of global legal pluralism and aim to refine the field based on recent research. The result, I hope, will be to re-energize and engage global legal pluralism scholarship and push its trajectory forward into another two decades of innovation.

* I am grateful to Keturah Taylor for useful research assistance in the final stages of preparing this chapter.

1 PS Berman, Global Legal Pluralism: A Jurisprudence of Law Beyond Borders (Cambridge, Cambridge University Press, 2012). The present chapter includes material derived from this book. 
It is particularly important that this engagement with global legal pluralism occur as part of a collection devoted to the idea of authority. At the core of all work on global legal pluralism is the question of authority. Pluralists recognize that authority is never either singular or total. Rather, any claim to authority immediately faces contestation, competition, and resistance from other claims to authority. Accordingly, those who seek to assert authority must always contend with a world of multiple jurisdictional claims. Pluralism provides a useful framework for conceptualizing the contestation and the inevitable negotiations that result.

\section{THE EMERGENCE OF GLOBAL LEGAL PLURALISM}

Legal pluralists have long recognized that societies consist of multiple overlapping normative communities. These communities are sometimes state-based but sometimes not, and they are sometimes formal, official, and governmental, but again sometimes they are not. Scholars studying interactions among these multiple communities have often used the term 'legal pluralism' to describe the inevitable intermingling of these normative systems. ${ }^{2}$

The study of plural normative systems has arisen from a variety of different scholarly traditions. Perhaps the earliest studies of the clashes between state and non-state authority were those penned by lawyers, philosophers, and theologians interested in the respective realms of

2 The history of 'legal pluralism' is a matter of some debate. Some associate the term with legal anthropology, see, e.g., BZ Tamanaha, 'The Folly of Legal Pluralism' (1993) 20 Journal of Law and Society 192; SE Merry, 'Legal Pluralism' (1988) 22 Journal of Law and Society 869, while others, see, e.g., F Benda-Beckmann, 'Citizens, Strangers, and Indigenous Peoples: Conceptual Politics and Legal Pluralism' (1997) 9 Law and Anthropology 1, trace the use of the term to lawyers: see MB Hooker, Legal Pluralism: An Introduction to Colonial and Neo-Colonial Laws (Oxford, Clarendon Press, 1975). Still others see legal pluralism deriving from church/state conflicts-of-law analysis, see, e.g., M Galanter, 'Justice in Many Rooms: Courts, Private Ordering, and Indigenous Law' (1981) 19 Journal of Legal Pluralism 1. For discussions of the history of 'legal pluralism', see J Griffiths, 'What is Legal Pluralism?' (1986) 24 Journal of Legal Pluralism 1; Merry, above; J Vanderlinden, 'Return to Legal Pluralism' (1989) 28 Journal of Legal Pluralism 149; B de S Santos, 'Law: A Map of Misreading: Towards a Post-Modern Conception of Law' (1987) 14 Journal of Law and Society 279; Benda-Beckmann, above; Tamanaha, above. 
church and state authority. ${ }^{3}$ Likewise, historians analysing the regulatory role of non-state entities such as jockey clubs and stock exchanges noted that these entities often wield more power than formal state law. ${ }^{4}$ Others have emphasized jurisdictional contestation as a core feature of the creation and maintenance of empires. ${ }^{5}$ Anthropologists used the idea of legal pluralism to conceptualize the relationship between colonial and indigenous legal systems. ${ }^{6}$ Social norms theorists ${ }^{7}$ and scholars in behavioural law and economics ${ }^{8}$ have become interested in forms of informal law that often regulate behaviour as much as, or more than, official governmental pronouncements. And legal and political theorists have sometimes focused on so-called 'soft law' instruments and their real-if informal—effect on behaviour. ${ }^{9}$

In recent decades, a new application of pluralist insights has emerged in the international and transnational realm. This new legal pluralism research was born in the decades following the collapse of the bi-polar Cold War order in 1989. During this period, it became clear that a single-minded focus on state-to-state relations or universal overarching norms was inadequate to describe the reality of the emerging global legal system, with its web of jurisdictional assertions by state, international, and non-state normative communities. As one commentator put it:

The nation-state and the interstate system are the central political forms of the capitalist world system, and they will probably remain so for the foreseeable future. What has happened, however, is that they have become an inherently contested terrain, and this is the central new fact on which the analysis must focus: the state and the interstate system as complex social fields in which

3 See, e.g., JN Figgis, Churches in the Modern State (London, Longmans, Green, 1913).

4 See, e.g., FW Maitland, 'Trust and Corporation' in HD Hazeltine, G Lapsley, PH Winfield (eds), Maitland: Selected Essays (Cambridge, Cambridge University Press, 1936) 141-222.

5 See, e.g., L Benton and RJ Ross (eds), Legal Pluralism and Empires, 1500-1850 (New York, New York University Press, 2013).

6 See, e.g., L Pospisil, 'Modern and Traditional Administration of Justice in New Guinea' (1981) 19 Journal of Legal Pluralism 93.

7 See, e.g., RC Ellickson, Order Without Law: How Neighbors Settle Disputes (Cambridge MA, Harvard University Press, 1991).

8 See, e.g., C Jolls, C Sunstein and R Thaler, 'A Behavioral Approach to Law and Economics' (1998) 50 Stanford Law Review 1471.

9 See, e.g., C Brummer, Soft Law and the Global Financial System: Rule Making in the 21st Century, 2nd edn (Cambridge: Cambridge University Press, 2015). 
state and non-state, local and global social relations interact, merge and conflict in dynamic and even volatile combinations. ${ }^{10}$

Legal pluralism provided a useful alternative framework because pluralism had always sought to identify hybrid legal spaces, where multiple normative systems occupied the same social field. And though pluralists had often focused on clashes within one geographical area, where formal bureaucracies encountered indigenous ethnic, tribal, institutional or religious norms, the pluralist lens proved highly adaptive to analysis of the hybrid legal spaces created by a different set of overlapping jurisdictional assertions (state v. state; state v. international body; state v. non-state entity) in the global arena.

An emphasis on legal pluralism also freed scholars from endless intractable debates about whether international law is truly law given that coercive enforcement power in the international and transnational arena is often indirect or non-existent. Such debates had created stagnation in the international law and international relations literature as both international law triumphalists and nation-state sovereigntists talked past each other with either an overly formalist faith in international law's inherent authority, on the one hand, or an overly formalist rejection of any law beyond the nation-state, on the other.

Global legal pluralism applies the insights of socio-legal scholarship and turns the gaze away from abstract questions of legitimacy and towards empirical questions of efficacy. Thus, pluralists de-emphasize the supposed distinctions between a norm, a custom, a law, a moral command, a sociological consensus, a psychological imperative, or the like. Instead, a pluralist approach focuses on whether people in actual practice perceive such legal or quasi-legal commands to be binding, how these commands seep into consciousness over time, and whether the mere existence of these commands alters the power dynamics or options placed on the table in policy discussions. Of course, questions of legitimacy and efficacy are inextricably linked (see Roughan in this volume), but the point is that once we come to recognize multiple sources of transnational and non-state authority, it is difficult to maintain any single abstract conception of legal authority. At best, authority is always relative and always contested, and our models for describing law should reflect that pluralism.

Finally, global legal pluralism has both a descriptive and normative component. Anthropologists and historians have generally framed the

10 B de S Santos, Toward a New Legal Common Sense: Law, Globalization, and Emancipation (London, Butterworths LexisNexis, 2002) 94. 
study of legal pluralism in descriptive terms. Accordingly, they have catalogued the inevitable hybridity that arises when two legal or quasilegal systems occupy the same social space, as well as the resulting strategic interactions that occur among actors in navigating the multiple regimes. As a descriptive enterprise, legal pluralism is relatively uncontroversial. After all, even the most die-hard sovereigntist would likely acknowledge that sub-, supra-, or non-state normative systems do impose real constraints that have real impacts. More controversial is the idea that legal pluralism might be a normatively desirable approach to the design of legal systems.

As a normative project, legal pluralism can be seen to support two different strategies. First, what we might call substantive legal pluralism generally seeks maximal accommodation of alternative norms, at least in certain delineated spheres. This is essentially a multiculturalist project, and it sometimes runs up against objections that it defers too much to illiberal norms. Second, a more proceduralist vision of legal pluralism aims to design procedural mechanisms, institutions, and discursive practices that seek to manage pluralism, without making a priori substantive decisions regarding when deference to alternative norms is appropriate and when it is not. This proceduralist version of legal pluralism's normative project argues that the mechanisms, institutions, and practices that result may at times be preferable to either sovereigntist territorialism on the one hand, or universal harmonization on the other. Moreover, such a proceduralist version of legal pluralism, unlike the substantive version, need not commit one to a programme of inevitable deference even to illiberal norms. Nevertheless, this proceduralist approach, precisely because it refuses to engage with some of the most contentious substantive political battles over when deference is appropriate and when it is impossible, may be distrusted or rejected by those on both sides of the pluralism debate who want more substantive normative certainty.

\section{GLOBAL LEGAL PLURALISM AND THE CONCEPT OF AUTHORITY}

Instead of focusing on states, pluralists tend to think in terms of multiple authorities. Moreover, they realize that all authority is inevitably only relative, not absolute, and all the more so given the increasing number of transnational and non-state claims to authority. In such a world, a burgeoning collection of authorities inevitably overlaps, interacts, negotiates, and accommodates. These authorities inhabit jurisdictional spheres 
that are often contested, and so the goal of most pluralist projects, at root level, is to describe and conceptualize the interactions.

This idea of relative authority, however, immediately sets up a theoretical conundrum because at least some conceptions of authority depend as a definitional matter on that authority being absolute, not relative. Indeed, some argue that a relative authority is not a true authority at all. For example, Joseph Raz, in The Authority of Law, argues that central to 'the uniqueness of law' is law's claim to comprehensive authority and supremacy. ${ }^{11}$ According to Raz, 'Since all legal systems claim to be supreme with respect to their subject-community, none can acknowledge any claim to supremacy over the same community which may be made by another legal system.' 12

The problem is that even if Raz's approach were supportable as an abstract philosophical matter (itself a debatable assumption), an absolutist conception of legal authority is often simply inadequate to fully describe or analyse the transnational world of tangled legal and quasilegal obligations and influences we see around us. Not surprisingly, pluralists challenge such a conception. Most recently, Nicole Roughan, in Authorities, directly addresses Raz's argument that a legal system by its nature must claim supremacy over other legal systems. To Roughan, Raz's argument suffers from both empirical and analytical difficulties.

As an empirical matter, she argues that the supremacy claim runs counter to actual legal practice, at least in Europe, which features 'many prima facie legal systems, including those of municipal states, that do not claim supremacy over all others, or even claim subjection to others'. ${ }^{13}$ Other pluralists agree. For example, Nico Krisch surveys what he calls 'the pluralist structure of postnational law', finding, in instance after instance, a more fluid framework that has no categorical separation among legal spheres, but that also does not fully merge them or even define 'the degree of authority' that the norms of these different spheres actually possess. ${ }^{14}$ Likewise, Keith Culver and Michael Giudice detail many areas where legal hierarchies are not stable, including federal and

11 J Raz, The Authority of Law, 2nd edn (Oxford, Oxford University Press, 2011) $117-21$.

12 Ibid 119.

13 N Roughan, Authorities: Conflicts, Cooperation and Transnational Legal Theory (Oxford, Oxford University Press, 2013) 155.

14 N Krisch, Beyond Constitutionalism: The Pluralist Structure of Postnational Law (Oxford, Oxford University Press, 2010) 12. See also Krisch's chapter in this volume. 
quasi-federal states, as well as states that maintain domains of overlap among concurrent authorities. ${ }^{15}$

Turning to Raz's more fundamental, analytical claim, Roughan argues that what pluralists need to develop, in order to combat Raz's monist conception, is an 'account of law that explains how different supremacy claims can be integrated and mutually recognized while upholding the authority of law' ${ }^{16}$ Her idea of relative authority aims to provide such an account. She argues that a legal system need not recognize another system as superior; it only needs to 'recognize the relativity of its own claim to the claim of others, and of their claims to its own' ${ }^{17}$ Thus, instead of seeing supremacy as a necessary precondition to law, Roughan offers a model of relative authorities that must 'cooperate, coordinate, or tolerate one another if they are to have legitimacy'. ${ }^{18}$ In this model, the claim to legitimate authority actually occurs through interdependence and interaction. The result is not that authority is reduced. Rather, the claim to authority is actually inextricably linked to its interdependence with other similarly relative authorities.

The pluralist model of relative overlapping authorities, therefore, is not necessarily a claim that traditional municipal legal systems have diminished authority in the 21 st century (though that might be true in some circumstances). Accordingly, one does not need to believe that nationstates have become irrelevant in order to embrace a pluralist perspective. To the contrary, their relevance is now bound up in their ability to negotiate pluralism. Thus, when Krisch and others describe a "postnational' order, it is not because they believe that we are done with nation-states. But what we might be done with is the (perhaps always fictitious) idealized vision of the nation-state as a single authority operating autonomously within bounded territory. 'Post' in this case, means 'after', but not in the sense of nation-states no longer existing; instead we are 'after' the nation-state only in the sense of being after a particular moment when nation-states were conceptualized in an autonomous absolutist way.

Indeed, sometimes a claim to relative authority may actually be stronger than a similar claim to absolute authority. For example, Krisch describes instances when lower courts within European countries have invoked the authority of the European Court of Human Rights to increase

\footnotetext{
15 K Culver and M Giudice, Legality's Borders: An Essay in General Jurisprudence (New York, Oxford University Press, 2010).

16 Roughan 2013, above n 13, 157.

17 Ibid.

18 Ibid 8.
} 
their own authority within the domestic judicial system. ${ }^{19}$ In such cases, by intertwining their authority with others they may actually increase their authority rather than reduce it. Likewise a private arrangement created by non-state actors can build authority by imbricating its regime with state entities. Conversely, nation-states can sometimes piggy-back on the superior enforcement power of non-state entities in order to effectuate claims to authority. In all of these cases, mastering the negotiation among relative authorities can actually increase power. Thus, the nation-state may emerge just as powerful as before or even more so, but it will derive its authority not from its autonomy but from its relationships with other authorities.

\section{GLOBAL LEGAL PLURALISM AND NON-STATE AUTHORITIES}

Those other authorities, while they can be state-based, also include a much broader set of possible jurisdictional entities, some associated with the state and some not. For example, many associations 'claim to possess - and attempt to exercise - a measure of legitimate authority over their members, and assert that this authority does not derive from the magnanimity of a liberal and tolerant state but is grounded, rather, on the common practices and aspirations of those individuals who choose to take part in a common endeavor'. ${ }^{20}$

If such plural sources of authority exist, then as Victor Muñiz-Fraticelli has recently argued, 'some of the central claims of republicanism must be false, or at least be subject to perpetual contestation'. ${ }^{21}$ This is because 'any sufficiently strong loyalty to any group but the political community would prevent the state's monopolistic exercise of sovereignty'. ${ }^{22}$ To pluralists, this is potentially a 'salutary effect of pluralism', ${ }^{23}$ but then what to do if an illiberal association or community pursues rightsdenying or otherwise destructive agendas? How does a state respond in such circumstances?

19 N Krisch, 'The Open Architecture of European Human Rights Law' (2008) 71 Modern Law Review 183.

20 V Muñiz-Fraticelli, The Structure of Pluralism: On the Authority of Associations (Oxford, Oxford University Press, 2014) 1.

21 Ibid 4.

22 Ibid.

23 Ibid. 
Different strands of pluralism provide different answers to this question. Some introduce a variation on the idea of judgment recognition. The idea here is that, although a community might be free to articulate a norm and apply it within its sphere, that does not necessarily mean others will blindly follow, recognize, or enforce the norm, particularly if it violates fundamental norms or values of the enforcing community. This conception of judgment recognition potentially helps prevent the spread of a noxious idea, but it might nevertheless seem to leave the community free to pursue its agenda within its own 'private' sphere. For example, a liberal state might create a space for sharia law to be practised within certain enclaves, while refusing to recognize and enforce such norms for non-members of the enclaves. Such an arrangement, however, still raises the question of whether such a policy commits the state to accept any and all judgments and punishments the court might mete out even within the enclave?

Some pluralists would say yes. For example, Alexis Galán and Denis Patterson have argued against a relatively moderate and restrained argument I made in my monograph, Global Legal Pluralism: A Jurisprudence of Law Beyond Borders. I suggested that liberal communities might try to open limited space for sharia courts to operate so long as those courts do not trench upon fundamental values of the liberal community. And it should be noted that even that moderate and restrained version of the argument draws fire from critics across the political spectrum, from rights advocates worried about illiberal practices to nation-state sovereigntists worried about giving any authority at all to non-state community ties. Patterson and Galán, in contrast, want to push much further. They claim that it's not really pluralism unless I go all the way and advocate that liberal communities allow sharia courts to operate regardless of whether or not they violate fundamental values of the liberal community. ${ }^{24}$ This strikes me as unnecessarily extreme. Just because one embraces insights from legal pluralism, after all, does not mean that the values of pluralism must necessarily and always trump any other values a community might hold. It simply cannot be that legal pluralism is only a true normative position if it is pursued to the exclusion of all other values, interests, and commitments.

Other pluralists also push back against the extreme view Galán and Patterson suggest. They envision the relationship of state and association

24 A Galán and D Patterson, 'The Limits of Normative Legal Pluralism: Review of Paul Schiff Berman, Global Legal Pluralism: A Jurisprudence of Law Beyond Borders' (2013) 11 International Journal of Constitutional Law 783. 
as one of reciprocal deference, not mutual independence and antagonism. The state recognizes it cannot fully dictate or control, and so instead relies on 'policies that set incentives or encourage alternative sources of public goods'. ${ }^{25}$ In turn, associations 'should accept certain normative conditions for reciprocal attenuation of conflict' ${ }^{26}$ Dwight Newman has even gone so far as to lay out a mutuality principle that an association must obey: 'a collectivity's claims to rights must be respectful of equivalently weighty interests of non-members' ${ }^{27}$

The problem with principles such as Newman's, as attractive as they are, is that they still assume that it is a liberal state that has the authority or simply the power to make judgments regarding the application of the mutuality principle. That might be true when a non-state community claims limited autonomy within a powerful liberal state. But pluralism encompasses many areas of the globe where the state is absent or where the power to enforce is at the very least shared between the state and other entities that may contest the state's legitimacy. In those circumstances, there may be little or no way of enforcing a mutuality principle, and the judgment recognition regime described above may be the best we can do.

\section{GLOBAL LEGAL PLURALISM AND CONFLICT OF LAWS}

The rise of global legal pluralism has brought renewed focus to the core principles of conflict of laws (sometimes called private international law): jurisdiction, choice of law, and recognition of judgments. In a world of multiple legal and quasi-legal pronouncements, these doctrines become a core way of navigating the interactions, using principles that derive from both legal formalism and political practicality. As Ralf Michaels observes, if the reality we face is legal fragmentation, the discipline most suited to deal with conflicts among legal orders is 'the discipline that was made for that precise purpose' ${ }^{28}$ Along the same lines, Christian Joerges has conceptualized the European Union as a

\footnotetext{
25 Muñiz-Fraticelli 2014, above n 20, 4.

26 Ibid.

27 D Newman, Community and Collective Rights: A Theoretical Framework for Rights Held by Groups (Oxford, Hart, 2011) 131.

28 R Michaels, 'Post-critical Private International Law: From Politics to Technique' in H Muir Watt and D Fernández-Arroyo (eds), Private International Law and Global Governance (Oxford, Oxford University Press, 2014) 54-67.
} 
conflict-of-laws regime. ${ }^{29}$ And Gunther Teubner has called for a radical reshaping of conflict of laws to address conflicts among societal systems, not just laws. ${ }^{30}$

It is true that conflicts doctrines cannot definitively solve problems of legal pluralism. Indeed, every historical effort to establish rules to resolve such conflicts has run into unsolvable problems, both theoretical and practical. So perhaps the field of conflicts of law is not really a stable legal doctrine at all? Is it just a matter of political choice dressed up in legal clothing? Of course, that is a charge potentially leveled at all legal doctrine and not without some truth behind it.

But just because politics inevitably pervades law does not mean legal doctrine is irrelevant or has no impact. And in the realm of conflict of laws, simply conceiving of a battle between state and non-state law in terms of conflicts doctrine will tend to change the framework of decision. Because non-state law-making is not usually conceived of as law, we do not often think of clashes between state and non-state law through the prism of conflict-of-laws jurisprudence. But we could. By way of example, consider two classic US constitutional cases that are usually framed as issues of religious or ethnic toleration, but which can also be analysed in terms of choice of law.

First, in Bob Jones Univ. v. United States, ${ }^{31}$ the Internal Revenue Service had interpreted section 501(c)(3) of the Internal Revenue Code, which gives tax-exempt status to qualifying charitable institutions, to apply to schools only if such schools have a 'racially nondiscriminatory policy as to students'. Accordingly, the Service denied tax exemption to Bob Jones University, which had not admitted blacks at all until 1971 and had admitted them thereafter but had forbidden interracial dating, interracial marriage, the espousal of violation of these prohibitions, and membership in groups that advocated interracial marriage. Crucial to the case was the fact that the University grounded its rule not on racial attitudes, but on Biblical scripture. The school therefore considered the exclusion of interracial dating to be a principal tenet of its religious community. Nevertheless, although the text of section 501(c)(3) did not speak to racial discrimination at all, the Supreme Court upheld the IRS

29 C Joerges, 'Reconceptualizing the Supremacy of European Law: A Plea for a Supranational Conflict of Laws' in B Kohler-Koch and B Rittberger (eds), Debating the Democratic Legitimacy of the European Union (New York, Rowman \& Littlefield, 2007) 311-27.

30 G Teubner, Law as an Autopoietic System, transl. A Bankowska and R Adler (Oxford, Blackwell, 1993).

31461 US 574 (1983). 
determination, finding the service's interpretation of the Code provision to be permissible.

Robert Cover famously criticized the reasoning of the Bob Jones decision, even while agreeing with the Court's result. According to Cover, the Court assumed 'a position that places nothing at risk and from which the Court makes no interpretive gesture at all, save the quintessential gesture to the jurisdictional canons: the statement that an exercise of political authority was not unconstitutional'. ${ }^{32}$ In particular, Cover argued that, by grounding its decision on an interpretation of the Internal Revenue Code, the Court had side-stepped the crucial constitutional question of whether Congress could grant tax exemptions to schools that discriminated on the basis of race. This was a problem for Cover because he believed that if a state legal authority were going to 'kill off' the competing normative commitment of an alternative community, it should do so based on a profound normative commitment of its own. By avoiding the constitutional question, Cover complained, the Court had both undermined the religious community-whose normative commitments would be placed at the mercy of mere public policy judgments - and at the same time undermined racial minorities-who 'deserved a constitutional commitment to avoiding public subsidization of racism'. ${ }^{33}$

In contrast, had the clash between the University's religious rule and the IRS Code, or between the religious rule and the US Constitution, been viewed as a choice-of-law decision, two aspects of the case would have been clarified. First, the Court would have analyzed and defined the relevant community affiliations at stake. Second, the Court would have been forced to grapple with the strength of its commitment to the principle of non-discrimination, just as Cover urged. As a result, instead of simply asserting federal law, a conflicts analysis encourages negotiation among the different norms advanced by different communities.

A more pluralist vision of conflict of laws recognizes that people and groups hold multiple community affiliations and takes those affiliations seriously. Thus, when a non-state legal practice is largely internal and primarily reflects individuals' affiliation with the non-state community, the practice should be given more leeway than when the state itself is part of the relevant affiliation. In this case, the issue at stake was a tax exemption, a quintessentially state matter. Indeed, Bob Jones University

32 RM Cover, 'The Supreme Court, 1982 Term - Foreword: Nomos and Narrative' (1983) 97 Harvard Law Review 4.

33 Ibid 67. 
was asking for a particular benefit for charitable organizations that was contained in the US tax code. Therefore, for these purposes the place of the university within the nation-state was the most salient tie, making application of the federal law more justifiable. In contrast, as we shall see, other non-state normative commitments do not implicate the nationstate so directly.

Moreover, even if the relevant community tie were largely with the religious community itself, certain norms might be held so strongly by the nation-state community that such norms would be applied regardless of the community affiliation. In choice-of-law analysis, this is usually called the public policy exception, and it allows courts to refuse to apply foreign law that would otherwise apply, if those legal norms are sufficiently repugnant. But application of the public policy exception is rare, both as a normative and descriptive matter. Thus, if a court asserts such an exception, it must justify the use of public policy grounds by reference to precisely the sorts of deeply held commitments that Cover envisioned. In the Bob Jones case, for example, it might be that the nation-state's deep commitment to eradicating racial discrimination would independently justify overriding the religious norms, regardless of the community affiliation analysis.

Accordingly, a conflicts approach would not simply throw the claim of protected religious insularity to the mercy of political or bureaucratic judgments. Taking the ban on interracial dating seriously as law and performing a choice-of-law analysis would create the obligation to engage in crucial line-drawing. And, while the community affiliation and public policy exception analyses in this case might justify application of state law, that will not always be the case.

Consider, by way of contrast, Employment Div., Dept. of Human Resources of Oregon v. Smith, ${ }^{34}$ in which the Supreme Court refused to extend First Amendment protection to the religious use of peyote by a tribal community. Here, unlike the tax exemption at issue in Bob Jones, the tribe was not negotiating its relationship with the state; rather the use of peyote was part of a purely internal religious practice open primarily (or exclusively) to members of that community. Thus, a choice-of-law analysis based on community affiliation might well result in deference to the non-state norm. Moreover, the normative commitment to drug enforcement is perhaps better characterized as a governance choice than as an inexorable normative command. As such, the public policy exception is arguably less appropriate in this context than when addressing

34494 US 872 (1990). 
racial discrimination. Applying these principles, a choice-of-law analysis might well have permitted the religious practice in Smith.

In the end, however, I am less concerned with the outcome in particular cases than with the analytical framework employed. Conceiving of these clashes between religious and state law in conflicts terms reorients the inquiry in a way that takes more seriously the non-state community assertion. As a result, courts must wrestle both with the nature of the multiple community affiliations potentially at issue and with the need to articulate truly strong normative justifications for not deferring to the non-state norm. Both consequences make the choice-of-law decision a constructive terrain of engagement among multiple normative systems, rather than an arm of state government automatically and without reflection imposing its normative vision on all within its coercive power. In a similar vein, Karen Knop, Ralf Michaels, and Annelise Riles describe conflict of laws doctrines not as truly fixed rules that dictate outcomes, but as technique: a discursive framework that structures thought. ${ }^{35}$

We can also usefully evaluate judicial opinions, legacies, and philosophies through the lens of legal pluralism by considering how judges try to navigate conflicts among legal systems. This interpretive lens focuses less on substantive outcome or political labels such as liberal or conservative and more on the way in which the judge understands his or her role in an interlocking, multijurisdictional legal tapestry. And given that judges inevitably face questions involving the interaction of legal systems, we can legitimately ask how each judge seeks to negotiate the hybrid spaces that result. Thus, a pluralist framework provides an untapped means of considering jurisprudential legacies. For example, examining Justice Ruth Bader Ginsburg's work as professor, judge and justice through a pluralist lens reveals a consistent theme in Ginsburg's jurisprudence. ${ }^{36}$ Across a variety of substantive legal areas, Ginsburg often chooses a path that provides maximum play among the legal systems at issue. Beginning with her earliest scholarly writings, she has tended to oppose doctrines allowing one legal system to block another from adjudicating a dispute, and throughout her later career Ginsburg likewise has tended to reject bright-line rules that choose one legal

35 K Knop, R Michaels and A Riles, 'From Multiculturalism to Technique: Feminism, Culture, and the Conflict of Laws Style' (2012) 64 Stanford Law Review 589.

36 PS Berman, 'Ruth Bader Ginsburg and the Interaction of Legal Systems' in S Dodson (ed), The Legacy of Ruth Bader Ginsburg (New York, Cambridge University Press, 2015) 151-71. 
system over another. Instead, she often seems to prefer procedural arrangements that seek accommodation and flexibility in order to ensure that multiple legal systems and a variety of norms and processes are respected. Thus, an emphasis on mechanisms for managing pluralism illuminates tendencies in her judicial approach that otherwise may have escaped notice. Similar analyses of other judges or the effects of different jurisprudential approaches may well follow over time.

\section{GLOBAL LEGAL PLURALISM AND CONSTITUTIONALISM}

Given that global legal pluralism has increasingly focused on procedural mechanisms and institutional designs for managing the interactions of legal systems, it is not at all surprising that those interested in global constitutionalism have at times embraced insights from legal pluralism. Such scholars seek structures to guide constitutive systemic interactions beyond the nation-state, and pluralism can offer a helpful rubric for building such structures. On the other hand, because pluralism tends to emphasize procedures rather than substantive norms, those seeking a more robust set of transnational constitutional normative commitments may reject or challenge what they view as the weak pull of pluralism.

The move to marry constitutionalism and pluralism has arisen principally in the context of European integration. ${ }^{37}$ As far back as 1995, Neil MacCormick used pluralism to provide an alternative constitutional vision to the then-prevalent internationalist position that emphasized the inherent supremacy of pan-European institutions. In justifying the Maastricht decision of the German Federal Constitutional Court, MacCormick suggested that unconditional acceptance of European Court of Justice decisions was not the only possible way to conceive of the increasingly integrated union. Instead, MacCormick argued that:

The most appropriate analysis of the relations of legal systems is pluralistic rather than monistic, and interactive rather than hierarchical. The legal system of Member States and their common legal system of EC law are distinct but interacting systems of law, and hierarchical relationships of validity within

37 E.g., M Avbelj and J Komárek (eds), Constitutional Pluralism in the European Union and Beyond (Oxford, Hart, 2012). 
criteria of validity proper to distinct systems do not add up to any sort of all-purpose superiority of one system over another. ${ }^{38}$

Subsequently, MacCormick, in Questioning Sovereignty, laid out the basic tenets of a theory of European constitutional pluralism: plural normative orders each acknowledging the legitimacy of the others, and none asserting superiority. ${ }^{39}$

Neil Walker generalized the idea of constitutional pluralism beyond the European context. ${ }^{40}$ Walker argued that the Westphalian state no longer held a monopoly of legitimate authority and that the world was better conceptualized as a site of contestation among multiple authorities with no Archimedian point from which conflicting claims to authority can be reconciled. Thus, according to Walker, we are better served by seeking a constitutional discourse built on mutual recognition and respect for other potential law-making authorities.

Significantly, as Walker's work makes clear, legal pluralism provides a way to invigorate constitutional discourse by reorienting it away from the structure of a single state and towards a discussion of how to manage constitutive interactions among multiple normative systems. In an era of fragmented and relative authority, one might think that constitutions no longer matter as much. But that is only if we think of constitutionalism as solely the province of states and their internal institutions. If instead we see constitutionalism as setting the ground-rules for interaction among relative authorities, constitutionalism becomes more important than ever. As Matej Avbelj and Jan Komárek have recently argued, '[t]he world pervaded by plurality ... calls for a meta-language through which the actors situated at different (epistemic) sites could reflexively engage with each other by recognizing their differences with a simultaneous commitment to a certain shared framework of co-existence.' ${ }^{41}$ Constitutional pluralism potentially provides such a meta-language.

A pluralist framework recognizes that normative conflict is unavoidable and so, instead of trying to erase conflict, seeks to manage it through procedural mechanisms, institutions and practices that might at least draw the participants to the conflict into a shared social space. But what

38 N MacCormick, 'The Maastricht Urteil: Sovereignty Now' (1995) 1 European Law Journal 259, 265.

39 N MacCormick, Questioning Sovereignty: Law, State, and Nation in the European Commonwealth (Oxford, Oxford University Press, 1999).

40 N Walker, 'The Idea of Constitutional Pluralism' (2002) 65 Modern Law Review 317. See also Walker's chapter in this volume.

41 Avbelj and Komárek 2012, above n 37, 4. 
norms, procedures or institutional arrangements actually follow from an embrace of pluralism? Here, at least in the European context, we see a great divergence of opinion that can usefully be grouped into seven strands of thought. ${ }^{42}$

First, Joseph Weiler has argued that, as a sociological matter, Europe at least is already acting on a pluralist constitutional base. ${ }^{43}$ According to Weiler, the European Union is founded on principles of mutual recognition and institutional deference and tolerance. Further, those principles are played out in the day-to-day decisions of all actors in the system, from low-level bureaucrats to high-level judicial authorities. Thus, Weiler argues that no further written constitutional document is necessary and that the norms such a document would inculcate already permeate the system. Weiler surfaces an important point that pluralists historically have adopted but that some constitutional pluralists may have forgotten: law exists in everyday practice and legal consciousness, not only in hierarchically determined formal legal structures. Accordingly, what we always need to study are the habits of mind that decision-makers and everyday people exhibit, regardless of the existence or non-existence of formal rules. From this perspective, Weiler is surely right that there can be a constitution in practice without a written document. On the other hand, it is also the case that formal structures and documents can, over time, come to influence habits of mind and day-to-day practices as part of a recursive feedback loop from doctrine to practice and back again.

Second, Walker's brand of constitutional pluralism resists some of the hierarchical dimensions of European integration far more than Weiler does. He therefore insists that the principles of mutual recognition and toleration be more formally built into the procedural mechanisms and structural documents of the EU. Thus, Walker is not willing to accept that pluralism is already sufficiently embedded in the structure of Europe. Rather he wants a more active and intentional engagement with the idea of constitutional pluralism. ${ }^{44}$

42 E.g., ibid; K Jaklic, Constitutional Pluralism in the EU (Oxford, Oxford University Press, 2014).

43 JHH Weiler, 'In Defence of the Status Quo: Europe's Constitutional Sonderweg' in JHH Weiler and M Wind (eds), European Constitutionalism Beyond the State (Cambridge, Cambridge University Press, 2003) 7-24.

44 E.g., N Walker, 'Constitutionalism and Pluralism in Global Context' in Avbelj and Komárek 2012, above n 37, 17-37. 
Third, some global constitutionalists, such as Mattias Kumm, ${ }^{45}$ are sceptical about pluralism's relentless focus on procedure and structure and therefore its resistance to articulating overarching substantive norms. According to Kumm, a pluralism aimed at fostering dialogue, tolerance, and mutual recognition is already sub rosa insisting on liberal norms and values even if it refuses to say so. Therefore, he argues, we should be explicit in championing a universal framework of shared liberal values including core norms of human rights and political participation. Here we see the flip side of the critique that Galán and Patterson advance, which was recounted earlier. Whereas Galán and Patterson criticize global legal pluralism for being too much like liberalism and therefore not pluralist enough, Kumm asks pluralists to embrace their liberal universalism and push further to actually advocate for global substantive constitutional values. The question, therefore, for global legal pluralists is whether there's a coherent middle ground between these two positions, one that embraces values of procedural and institutional interaction while honouring plural norms and resisting a universal framework of hierarchically imposed rights.

Fourth, we might see Miguel Maduro as trying to thread that very needle. ${ }^{46} \mathrm{He}$ repeatedly resists making strong claims about universal substantive norms while simultaneously requiring overarching procedural norms that require actors to justify their claims to authority. In this requirement (and in much global legal pluralist literature), we can hear echoes of Jürgen Habermas' discourse-based liberal theory. The question remains, though, whether the middle ground can be maintained. I believe it can. After all, even if one insists ultimately on an overarching norm of dialogue and toleration, that minimalist liberalism may be more palatable to those embracing competing views than the more robust package of substantive liberal rights advocated by Kumm. Thus, acknowledging a liberal core to global legal pluralism does not commit one to adopting every liberal substantive norm and then insisting on universal adoption of the entire package.

Fifth, we might include those who accept—or even celebrate-a limited range of plural systemic interaction even while tolerating (or advocating) a hierarchical legal order. Thus, in the United States many

45 E.g., M Kumm, 'Rethinking Constitutional Authority: On the Structure and Limits of Constitutional Pluralism' in Avbelj and Komárek 2012, above n 37, 39-65.

46 E.g., MP Maduro, 'Contrapunctual Law: Europe's Constitutional Pluralism in Action' in N Walker (ed), Sovereignty in Transition (Oxford, Hart, 2003) 501-38. 
who would in no way identify with pluralism nevertheless acknowledge the importance of state-based pluralism within a federalist legal structure. And even committed pluralists such as Robert Cover have celebrated federalism for allowing 'tensions and conflicts of the social order' to be played out in the jurisdictional structure of the system. ${ }^{47}$ Likewise, advocates of federalism emphasize the importance of having a multilayered, quasi-independent legal system, and they have sometimes applied such an approach to the supranational arena (at least within Europe).$^{48}$ But such multi-level constitutionalism tends to presuppose a hierarchically superior European sovereign that ultimately provides a single answer to constitutional conflict. Thus, its pluralism is sharply circumscribed.

Sixth, there are those who believe that supranational integration along constitutionalist lines is an impossibility. Instead, they argue for a 'directly deliberative polyarchy' that explicitly recognizes plural lawmaking authority by an overlapping network of private and public actors and bodies. ${ }^{49}$ This can hardly be called constitutionalism at all. Indeed, advocates of this approach argue that instead of thinking in constitutionalist terms we should be exploring ways in which the pluralist interactions among state and non-state regulatory bodies can be made more responsive, inclusive, and democratic.

Finally, there are those, such as Gunther Teubner, who see a global societal constitutionalism emerging through the interaction of social systems. ${ }^{50}$ This approach is more of a descriptive sociological project than a normative matter of political theory. But it effectively challenges all theories of global constitutionalism to recognize the real sources of power and authority at play in the world and the fact that the sources of that power and authority may in the end have nothing to do with any political theory of constitutional legitimacy, even pluralist ones.

47 RM Cover, 'The Uses of Jurisdictional Redundancy: Interest, Ideology, and Innovation' (1981) 22 William and Mary Law Review 639, 682.

48 E.g., D Halberstam, 'Systems Pluralism and Institutional Pluralism in Constitutional Law: National, Supranational and Global Governance' in Avbelj and Komárek 2012, above n 37, 85-125; S Piattoni, The Theory of Multi-Level Governance: Conceptual, Empirical, and Normative Challenges (Oxford, Oxford University Press, 2010).

49 E.g., O Gerstenberg and C Sabel, 'Directly Deliberative Polyarchy: An Institutional Ideal for Europe?' in C Joerges and R Dehousse (eds), Good Governance in Europe's Integrated Market (Oxford, Oxford University Press, 2002) 289-341.

50 G Teubner, Constitutional Fragments: Societal Constitutionalism and Globalization (Oxford, Oxford University Press, 2014). 
Thus, we can see that legal pluralism has usefully broadened the discourse about constitutionalism, especially in Europe. Whereas constitutions were historically the province of states and were most celebrated for the substantive rights recognized, the pluralist discourse turns the discussion to managing structural interactions among law-making entities on the state, sub-state, and supra-national level. This discussion has already borne significant fruit, both in the realm of scholarship and in the actual practice of institutions, where we see many structures and procedural mechanisms that embed pluralist principles into their constitutive frameworks. Such institutions, structures and mechanisms include coordinated judicial dialogue, margins of appreciation, hybrid tribunals, subsidiarity regimes, formal spheres for religious law, and so on. ${ }^{51}$ Over time, we can expect to see this discourse grow and to see more institutions built and procedural mechanisms developed with an explicit pluralist framework at their core.

On the other hand, perhaps we should move the whole constitutional debate beyond constitutionalism itself. After all, as Nico Krisch ${ }^{52}$ observes, the core idea of constitutionalism is grounded in the effort to define a 'people' or demos that can plausibly be tasked with selfgovernment. This effort might possibly be successful in the European context (though even there we see much cause for doubt), but it is far more difficult to imagine such a constitutionalism ever emerging globally, given the diversity that exists. Moreover, as Krisch argues, 'in these circumstances, the idea of settling the central questions of a polity in constitutionalist form may not only seem unachievable but also undesirable - respect for this diversity may require leaving those questions open, rather than closing the debate'. ${ }^{53}$ Accordingly, Krisch asks us to break out of the 'straitjacket that accompanies the quest for continuity with domestic concepts and traditions'. Instead, he suggests looking 'beyond constitutionalism for guidance and inspiration'. From Krisch's perspective pluralism is an alternative to global constitutionalism, not a set of principles that can be incorporated within constitutional discourse.

I am sympathetic with Krisch's position, and I agree that pluralism offers a radical critique of traditional constitutionalist thinking. However, I also believe that, at least judging from the constitutionalist discourse of the past 15 years, we are seeing the evolution of constitutionalism in a more pluralist direction. Thus, rather than rejecting the constitutionalist

51 For a discussion of these and other mechanisms, see PS Berman, 'Global Legal Pluralism' (2007) 80 Southern California Law Review 1155.

52 Krisch 2010, above n 14.

53 Ibid 68 . 
discourse altogether, I would be more inclined to continue the engagement and encourage the movement away from constitutionalism as demos construction and towards a vision of constitutionalism that seeks mechanisms and institutions that foster constitutive interaction among systems. The resulting constitutionalist structures and institutions would likely accord with Krisch's vision, even if he would refuse to use the label constitutionalist to describe them.

\section{GLOBAL LEGAL PLURALISM AND COSMOPOLITANISM}

Cosmopolitanism is often thought to be the opposite of pluralism because cosmopolitanism is seen as a justification for universal overarching norms that govern beyond and above the state. In this conception, cosmopolitanism is equated with universalism, and if that is the definition of cosmopolitanism then it does seem to be antithetical to pluralism. Certainly, from a pluralist perspective there are reasons to question both the desirability and the feasibility of universalism, at least in some contexts.

As to desirability, it is not at all clear that universalism is an unalloyed good. Indeed, if we think of ourselves solely as citizens of the world, we might tend to dissolve the multi-rootedness of community affiliation into one global community. Thus, universalism may fail to capture the extreme emotional ties people still feel to distinct transnational or local communities and therefore ignore the very attachments people hold most deeply.

In addition, universalism inevitably erases diversity. This is a problem for three reasons. First, such erasure may involve the silencing of less powerful voices. Thus, the presumed universal may also be the hegemonic. Second, preserving legal diversity can be seen as a good in and of itself because it means that multiple forms of regulatory authority can be assayed in multiple local settings. Just as states in a federal system function as 'laboratories' of innovation, so too the preservation of diverse legal spaces makes innovation possible. Third, a legal system that provides mechanisms for mediating diversity without dissolving difference necessarily also provides an important model for mediating diversity in day-to-day social life. For example, one argument for a strongly speech-protective interpretation of the First Amendment of the US Constitution is that the effort required to tolerate the provocative speech 
of others is the same effort required to tolerate others more generally. ${ }^{54}$ Thus, a legal system that demands tolerance of diversity rather than its erasure is more likely to create the context for a tolerant society than one that, in contrast, seeks uniformity as its goal.

Nevertheless, even if one rejects these normative arguments and embraces universalism as the appropriate path in the abstract, it is difficult to believe that, as a practical matter, harmonization processes will ever fully bridge the significant differences that exist among states, let alone the variety of non-state orders at play in the world. This is because many differences, both in substantive values and attitudes about law, arise from fundamentally different histories, philosophies, and worldviews. People are therefore likely to be either unable or unwilling to trade in their perspectives for the sake of universal harmony. Moreover, even if they were so inclined, it would be difficult to develop a process for determining which norms should be elevated to universal status and which should give way. Thus, when harmonization is possible, it is usually a slow, laborious undertaking, limited to codifying normative convergences that have already occurred over time. As a result, harmonization is generally backward-looking, and in a rapidly changing world, harmonization processes will tend to lag behind social, technological, and economic realities. Accordingly, even the most optimistic universalist would have to acknowledge that normative conflict is at the very least a constant transitional reality that will require hybrid processes to address.

But perhaps we can view cosmopolitanism as something different from universalism. After all, cosmopolitanism does not necessarily require a belief in a single global welfare or even a single universal set of governing norms, nor does it necessarily require that global welfare trump state welfare. Indeed, properly understood, cosmopolitanism need not be incompatible with pluralism. To the contrary, a more nuanced understanding of cosmopolitan theory offers a useful framework for conceptualizing the interplay of multiple actors in the transnational system we see operating today.

Cosmopolitanism is a useful trope for conceptualizing interaction across territorial borders precisely because it recognizes that people have multiple affiliations, extending from the local to the global (and many non-territorial affiliations as well). For example, Martha Nussbaum has stressed that cosmopolitanism does not require one to give up local identifications, which, she acknowledges, "can be a source of great

54 E.g., TI Emerson, Toward a General Theory of the First Amendment (New York, Vintage, 1966). 
richness in life'. ${ }^{55}$ Rather, following the Stoics, she suggests that we should think of ourselves as surrounded by a series of concentric circles:

The first one encircles the self, the next takes in the immediate family, then follows the extended family, then, in order, neighbours or local groups, fellow city-dwellers, and fellow countrymen - and we can easily add to this list groupings based on ethnic, linguistic, historical, professional, gender, or sexual identities. Outside all these circles is the largest one, humanity as a whole. 56

Therefore, we need not relinquish special affiliations and identifications with the various groups of which we may feel a part.

In this vision, people could be 'cosmopolitan patriots', accepting their responsibility to nurture the culture and politics of their home community, while at the same time recognizing that such cultural practices are always shifting, as people move from place to place or are increasingly affected by spatially distant actors..$^{57}$ 'The result would be a world in which each local form of human life is the result of long-term and persistent processes of cultural hybridization-a world, in that respect, much like the world we live in now. ${ }^{5} 8$

Thus, cosmopolitanism is emphatically not a model of international citizenship in the sense of global harmonization and standardization, but is instead a recognition of multiple refracted differences where people acknowledge links with the 'other' without demanding assimilation or ostracism. Cosmopolitanism seeks 'flexible citizenship', in which people are permitted to shift identities amid a plurality of possible affiliations and allegiances, including non-territorial communities. ${ }^{59}$ The cosmopolitan worldview shifts back and forth from the rooted particularity of

55 MC Nussbaum, 'Patriotism and Cosmopolitanism' in J Cohen (ed), For Love of Country?: Debating the Limits of Patriotism (New York, Beacon, 2002) 3-17, 9.

56 Ibid.

57 KA Appiah, 'Cosmopolitan Patriots' in P Cheah and B Robbins (eds), Cosmopolitics: Thinking and Feeling Beyond the Nation (Minneapolis, University of Minnesota Press, 1998) 91-116.

58 Ibid 92.

59 A Ong, Flexible Citizenship: The Cultural Logics of Transnationality (Durham NC, Duke University Press, 1999). 
personal identity to the global possibility of multiple overlapping communities. '[I]nstead of an ideal of detachment, actually existing cosmopolitanism is a reality of (re)attachment, multiple attachment, or attachment at a distance.' 60

In recent years, Patrick Glenn has offered a rich account of the role of nation-states within this kind of multiplicity. ${ }^{61} \mathrm{He}$ argues that there never has been and never will be a nation-state that was not ultimately cosmopolitan in character because all states exist as part of a world of relative overlapping authorities. In the end, he argues that we should look to the structural ways that states operate in and adapt to this cosmopolitan reality. And in doing so, he focuses on many of the same sorts of procedures and institutions that global legal pluralism has explored over the past two decades. A cosmopolitan pluralist conception of law, therefore, might be seen to capture a middle ground between strict territorialism on the one hand and expansive universalism on the other. A territorialist approach fails to account for the wide variety of community affiliations and social interactions that defy territorial boundaries. A more universalist perspective, by contrast, which seeks to imagine people as world citizens first and foremost, might seem to be a useful alternative. But such universalism tends to presuppose a world citizenry devoid of both particularist ties and normative discussion about the relative importance of such ties. Thus, universalism cuts off debate about the nature of overlapping communities just as surely as territorialism does.

A cosmopolitan pluralist conception, in contrast, makes no attempt to deny the multi-rooted nature of individuals within a variety of communities, both territorial and non-territorial. Thus, although a cosmopolitan pluralist conception might acknowledge the potential importance of asserting universal norms in specific circumstances, it does not require a universalist belief in a single world community. As a result, cosmopolitan pluralism offers a promising rubric for analysing law in a world of diverse normative voices.

Again, in this conception, cosmopolitanism and pluralism are in no way at odds. Cosmopolitanism recognizes multiple affiliation and overlapping community identification as well as multiple legal systems, whereas pluralism recognizes that these legal and quasi-legal systems can include both state and non-state entities. Thus, the evolution of global

60 B Robbins, 'Introduction: Actually Existing Cosmopolitanism' in Cheah and Robbins 1998, above n 57, 1-19, 3.

${ }^{61}$ HP Glenn, The Cosmopolitan State (Oxford, Oxford University Press, 2013). 
legal pluralism is fully compatible with cosmopolitan theory, at least as understood in this more nuanced framework.

\section{GLOBAL LEGAL PLURALISM AND INTERNATIONAL LAW}

For many years, international law triumphalists hoped that the rise of international legal institutions would resolve this messy world of regime collision and fragmentation by creating one over-arching, hierarchically superior set of norms that most people would follow most of the time. And yet, precisely as legal pluralism scholarship would predict, the hierarchy, once articulated, was immediately contested. Thus, international law, though it often has very real impact, ${ }^{62}$ ends up being one voice among many, all competing for authority. In addition, again as legal pluralism scholarship predicts, it quickly becomes clear that international law itself is not one entity. Instead, different international legal regimes, promulgated for very different reasons and administered by different tribunals and regulatory bodies, often conflict and collide with each other, leading to the need for negotiation, contestation and hybrid provisional compromises. ${ }^{63}$

In response to this pluralism, we could bemoan the 'fragmentation of international law' 64 and seek to stamp it out by trying to create rules of recognition that would declare one legal regime to be superior. This strikes me as a fool's errand given the diversity of the world's population. Alternatively, we could celebrate the multiplicity and devise strategies for managing, without eliminating, the inevitable pluralism around us. And if we do so, we may find that law already provides a language and a set of procedural mechanisms and discursive practices that might help negotiate across the fissures.

For example, Dirk Pulkowski has recently explored how this negotiation takes place in one particular substantive area: the regulation of trade

62 PS Berman, 'Seeing Beyond the Limits of International Law' (2006) 84 Texas Law Review 1265.

63 MA Young (ed), Regime Interaction in International Law: Facing Fragmentation (Cambridge, Cambridge University Press, 2012).

64 E.g., M Koskenniemi, 'Fragmentation of International Law: Difficulties Arising from the Diversification and Expansion of International Law' ILC, Study Group on Fragmentation of International Law (2006) UN Doc A/CN4/L682. 
in cultural products. ${ }^{65}$ Pulkowski observes that such regulation may arise from three distinct international regimes: the trade regime, the human rights regime, and the UNESCO culture regime. As Pulkowski notes, each of these three regimes may well promote 'different, and ultimately incommensurable, policy goals, such as open markets, diversity of cultural identities, and equal opportunities for cultural participation in a society'. ${ }^{66}$ So what happens when these regimes collide by pulling 'in different directions and towards different normative outcomes'? Each regime has similar authority; none is hierarchically superior to the other two. But does that mean that there is no possible response? Does the resulting legal pluralism render efforts to negotiate among the regimes useless?

Pulkowski thinks not. He argues instead that international law, even when it does not offer a hierarchically superior set of normative rules, provides interpretive strategies that can help develop what he calls 'inter-regime compatibility'. ${ }^{67}$ Indeed, although international law is not (and perhaps never will be) 'an integrated and fully unified system', it can be 'a common language for discursive engagement across regimes, based on shared, regime-transcendent discourse rules' ${ }^{68}$

What are these 'regime-transcendent' discourse rules? Not surprisingly, Pulkowski here turns away from substantive norms because it will always be difficult to choose a single set of such norms to govern. Instead, he focuses on interpretive and procedural mechanisms, which at least have the potential to forge provisional compromises among different normative systems. He argues that '[i]nternational law plays a useful role in bridging conflicting regimes' in two ways. ${ }^{69}$ First, international law offers canons of interpretation that can be used by actors within each of the three regimes to try to interpret norms with an eye towards overall systemic coherence. Second, if no systemic coherence is possible, international conflict-of-law rules can be used to determine which regime's norms to apply (or whether, perhaps, a hybrid can be forged).

Jeffrey Dunoff likewise has responded to concerns about fragmentation by playing out the question of regime interaction using the insights of

65 D Pulkowski, The Law and Politics of International Regime Conflict (Oxford, Oxford University Press, 2014).

66 Ibid 13.

67 Ibid 20.

68 Ibid.

69 Ibid. 
legal pluralism. ${ }^{70}$ But he argues that we should look beyond the more formal interactions and conflicts that Pulkowski emphasizes. Instead, Dunoff suggests that we should see all the various international regimes as norm-generating communities that interact in iterative ongoing relations, not in single discrete transactions.

For example, Dunoff analyses the international response to regulating hazardous chemicals and other substances. These regulatory efforts, 'have been marked,' he argues, 'by collaborations among international organizations that cross regimes'. ${ }^{71}$ Thus, the Inter-Organization Programme for the Sound Management of Chemicals includes actors from the World Health Organization, the Organization for Economic Cooperation and Development, the Food and Agriculture Organization, the International Labour Organization, the United Nations Environment Programme, and the United Nations Industrial Development Organization, with the World Bank and UN Development Programme participating as observers. The members of these widely varying regimes interact regularly to build broader regulatory initiatives. Likewise, The Stockholm Convention on Persistent Organic Pollutants 'explicitly structures an ongoing series of interactions between actors in the chemicals regime ... and actors in the public health regime ... over global efforts to create global regulations for dangerous pesticides'. ${ }^{72}$ And even absent explicit treaty commands, Dunoff highlights regime interactions such as the increasing dialogue between the human rights and climate change communities. According to Dunoff, this iterative relational process of norm creation is fundamentally different from Pulkowski's more transactional model that emphasizes jurisdictional boundaries, conflicts of law, and individualized decisionmaking. Instead, Dunoff describes the more inchoate ongoing conceptual interactions that over time change broad-based coalitions and normative understandings.

Both Pulkowski and Dunoff perform a useful service by playing out their strategies in specific contexts and doing so in a theoretically sophisticated and systematic way. This scholarship suggests that, in the end, international law's strength might be less its assertion of an absolute set of governing norms and more its provision of a language and a variety of forums for creative and fruitful contestation, compromise and norm development.

70 JL Dunoff, ‘A New Approach to Regime Interation' in Young 2012, above n 63 136-74.

71 Ibid 159.

72 Ibid 161. 


\section{GLOBAL LEGAL PLURALISM AND LIBERALISM}

If one is interested in non-state law-making, one is, almost by definition, drawn to legal pluralism (and global legal pluralism) as an interpretive lens. This is because while liberal legal theorists generally presume that state-based law trumps all competing normative systems, pluralists challenge the centrality of the state. Whether considering canon law or indigenous law or the law of ethnic groups, pluralists have long refused to accept that the state is the only relevant actor on the stage of law. As such, those most interested in charting the influence and power of non-state law-making have looked to legal pluralism as a possible solution to the problem of traditional liberal legality's state-centrism. And global legal pluralism adds transnational and international normative assertions into the mix, again challenging the presumed autonomy of state law.

But, when considering non-state actors and non-state law-making of various kinds, what does a pluralist perspective actually add to the classic liberal approach? After all, liberalism is not unalterably opposed to non-state norms, and even those who focus only on the central legal authority of the liberal state think it important that the state should sometimes defer to such norms. Indeed, one of the core notions of liberalism is that government should not take sides in debates about competing visions of the good, and therefore space is allowed for non-state normative commitments. So long as a non-state normative community does not infringe unduly on the rights of others, liberalism allows those communities a tremendous amount of freedom and scope. For their part most pluralists do not deny the importance of the state, nor even the fact that often the state has greater coercive power at its disposal and therefore is better able to enforce its norms than non-state entities are. After all, recognizing non-state law-making as important does not in and of itself mean that all sources of law are equally powerful or influential.

So, on the surface, it appears that legal pluralism and legal liberalism effectively merge into one. The merged statement reads something like this: 'The state is the most powerful lawmaker; it allows scope for non-state norms when it chooses to, and it often does choose to defer because non-state norms have a strong emotional pull and should be accorded deference as long as those norms don't get out of hand.' And if that's all legal pluralism is adding, then the voluminous legal pluralism scholarship does not appear to have altered the basic liberal legal framework very much.

Interestingly, this critique of legal pluralism - that it is not a radical re-shaping of the landscape but simply liberalism in another guise-is 
precisely the opposite of the criticism global legal pluralists usually receive. Typically, the worry is that a pluralist framework will give too mисh space for plural norms. Sovereigntists tend to object to the idea that nation-states should ever take into account international, transnational or non-state norms. Meanwhile, international law triumphalists chafe at the idea that international norms should ever be subordinated to local practices that may be less liberal or less rights-protecting. But both positions are principally concerned that global legal pluralism will result in too much fragmentation and too much deference to what are viewed as illegitimate norms.

In contrast, some critics view legal pluralism (or at least the proceduralist version of legal pluralism I have advocated in this chapter and elsewhere) as completely consonant with liberalism and therefore essentially conventional and not truly pluralist enough to provide a fully alternative vision. ${ }^{73}$ Accordingly, pluralists might actually be tempted to welcome this critique because it offers a response to those who claim pluralism is too extreme and destabilizing. After all, a position cannot easily be simultaneously too radical and not radical enough. Thus, pluralists might simply embrace the critique, allow for the fact that pluralism is less radical than some imagine, and end the discussion there.

And yet I think there's more to it than that. While pluralism need not be conceptualized as inconsistent with liberalism, it is also not precisely the same as liberalism. Instead, legal pluralism is significantly different from the classic liberal vision in at least two important ways, one descriptive and one normative.

First, as a descriptive matter, legal pluralists are far more likely than traditional liberals even to notice the pluralism of legal and quasi-legal norms that exist apart from the state. After all, most liberal theorists begin their analysis with the state: how it is formed, how it is justified, and the philosophical underpinnings for its operations. Non-state actors are surely important to this inquiry in that they clash with the liberal state, and of course the state, under liberalism, should often reach positions of accommodation with these non-state actors. But what is being described is fundamentally the state and how it views the non-state.

In contrast, pluralism assumes that the inquiry is the entire range of legalities that course through the everyday experience of people. This means that the lived reality of communities and day-to-day perceptions of legitimacy and efficacy are far more important than philosophical models. Moreover, a pluralist perspective is more likely to see individuals and

73 Galán and Patterson 2013, above n 24. 
groups, rather than just the state, as having agency and therefore playing crucial roles in navigating the interaction of normative systems and using those systems strategically.

For example, in the classic colonial interaction, a quasi-liberal, statebased legality was layered on top of an indigenous legal system. A liberal theorist would focus on the newly imposed system and on how it either accommodated or refused to accommodate local communities. In contrast, pluralists would observe that the colonial system did not wipe out the indigenous system altogether, and would then focus on the interaction of these legal systems and the way in which local actors used both systems strategically to gain leverage.

This is only one of many possible examples. But the point is that where liberalism only sees state legal systems and the challenges they face, pluralists will see interactions among legal systems. And global legal pluralism recognizes that nation-states must work within a framework of multiple overlapping jurisdictional assertions by state, international, and non-state communities. Each of these types of overlapping jurisdictional assertions creates a potentially hybrid legal space that is not easily eliminated.

Just as important, pluralists are much less likely to insist on positivist definitions of law and will therefore be willing to see law even in the absence of coercive power. This is especially significant in the global arena where statements of legal norms may be highly effective even in the absence of such formal enforcement power. ${ }^{74}$ For example, liberal sovereigntists sometimes insist that international, transnational and nonstate legal norms have no independent valence and that instead states simply pursue their own interests. In contrast, pluralists unpack the idea of a state interest, recognizing that conceptions of proper policy do not simply arise in a vacuum. Rather, they are developed by human beings operating with various sets of assumptions, ideas about justice, conceptions of global strategy, and beliefs about morality. These assumptions, ideas, and cognitive categories are themselves shaped in part by what socio-legal scholars have long termed legal consciousness. Accordingly, the legal norms that are 'in the air' at any given moment of historyincluding international, transnational and non-state legal norms-may well affect how both policy-makers and ordinary citizens think about the state's interests.

74 Eg, J Brunnée and SJ Toope, Legitimacy and Legality in International Law: An Interactional Account (Cambridge, Cambridge University Press, 2010). 
Thus, legal pluralism provides a richer account of how law actually operates, both domestically and internationally, than the positivist vision of liberal sovereigntism. We imbibe legal norms and cognitive categories even when we are not consciously aware of the norm in question. We are persuaded by legal norms even when those norms are not literally enforceable. We act in accordance with law because doing so has become habitual, not necessarily because we seek to avoid sanction. We conceive of our interrelations with others in terms of law because our long-term interests dictate that we do so, even when our short-term interest might seem to counsel otherwise. And the existence of a legal norm alters the constitutive terms of our relationships with others as well as the costs of noncompliance. All of these factors may be overcome in some circumstances. Indeed, people sometimes violate domestic law just as states sometimes violate non-state law. But in neither case does that mean that the law in question has no significant constraining force. And only by thinking more broadly about changes in legal consciousness and the complicated social, political, and psychological factors that enter into the conceptualization of state interests can we begin to understand how non-state law operates.

In addition, instead of treating the state as a unitary 'personality' with a single set of interests, pluralists recognize that the real world is far messier, with a vast number of constituencies both within the governmental bureaucracy and outside it. This cacophony of voices is important because many of these voices, when advocating policy positions, can use the moral authority or persuasive power of international, transnational and non-state norms for leverage. These norms therefore become a tool of empowerment for particular actors. And given that any state policy decision is inevitably the result of a contest among various bureaucratic power centres, all of which are themselves influenced by outside pressure groups, lobbyists, NGOs and the like, a more complex understanding of the global legal arena would need to explore ways in which plural legal norms empower specific interests both within and without the state policy-making apparatus.

In short, legal pluralism offers a more complicated descriptive account of the interaction of normative systems, the strategic action of individuals and groups in deploying these multiple systems to pursue their interests, and the subtle processes by which even norms without coercive power can change legal consciousness and gain efficacy over time. These nuances are often elided in the traditional liberal legal analysis. ${ }^{75}$

75 W van der Burg, The Dynamics of Law and Morality: A Pluralist Account of Legal Interactionism (Farnham, Ashgate, 2014). 
Second, as legal pluralism has developed a more normative bite, it has been used to justify procedural mechanisms, institutional designs and discursive practices aimed at developing habits of mind in decisionmakers that will encourage those decision-makers to use restraint in insisting jurispathically on their own norms to the exclusion of the norms of other communities. Thus, the key normative question from a pluralist perspective is not simply: here are my norms, now how much should I tolerate others? Instead, as discussed previously, this sort of proceduralist pluralism will favour hybrid institutional designs and practices that will embed principles of toleration and accommodation into day-to-day operations. These designs and practices may well be consonant with liberalism, but they result in a very different set of institutional arrangements, inquiries, and jurisprudential tropes from the standard version of liberal institutional tolerance.

For example, consider a governing council of decision-makers popularly elected by citizens of a community. Assume that every council member happens to be a member of the same majority ethnic, racial or religious group within that broader community. If the election were conducted fairly and the governing body does not unduly infringe minority rights in its substantive decisions, then under most theories of liberalism there is at least some justification for saying that this is a legitimate arrangement. If one embraces the vision of legal pluralism I pursue, however, one might reach the conclusion that even if this rule solely by members of the dominant group is legitimate, it is likely not preferable. This is because the procedural pluralist approach adds in a preference for greater dialogue among multiple communities to improve the quality of decision-making, to build habits of mind that inculcate tolerance, and to make it more likely that the minority will acquiesce in whatever substantive decisions are ultimately reached. Accordingly, following a more pluralist approach, one might decide to set aside certain seats on the governing council for the minority group. Either of these arrangements is likely compatible with liberalism; however, the pluralist perspective adds an additional set of considerations to weigh in the institutional design decision.

Thus, where liberal institutionalists might simply tolerate minority viewpoints, a commitment to pluralist arrangements might lead to institutional designs that require hybrid participation. Pluralist mechanisms can also create structural feedback loops, where institutional decision-makers are forced to consider the approaches of other communities. And while such mechanisms are not necessarily in opposition to liberalism, they instantiate a set of concerns about structural interactions that is distinct from liberalism. Finally, as discussed previously, a 
pluralist approach would also focus less on whether a state institution tolerates a non-state community from a position of inherent superiority and instead conceptualize the conflict between state and non-state law-making as a true conflict-of-laws problem.

In the end I believe global legal pluralism offers a fundamentally different analytical framework-both descriptively and normativelyfrom liberalism. And while it may be that a pluralist perspective can fit comfortably within a liberal philosophical stance (that depends on how far the pluralist impulse is pushed in particular cases), I think a pluralist perspective is likely to lead to both a more nuanced descriptive understanding of the world and a more desirable legal and political framework for addressing the hybridity that surrounds us every day.

\section{GLOBAL LEGAL PLURALISM, THE RULE OF LAW, AND DEMOCRACY}

As global legal pluralism has successfully put forth a viable alternative normative conception of the global legal order, we have seen, not surprisingly, challenges to this pluralist framework. These challenges most often focus on two dimensions: first, whether a pluralist framework undermines the stability and predictability that are the hallmarks of the rule of law; and second, whether acknowledging the potential efficacy of transnational, international and non-state law fundamentally undermines democratic principles by recognizing the importance of norms articulated beyond the state polity.

With regard to rule of law, the concern is that any theory that leaves supremacy claims undecided is simply a recipe for chaos. Yet, to some degree this is simply a reality of a multivariate world of relative authorities whether one embraces theories of pluralism or not. There is no way to escape chaos because any claim to superior authority will inevitably be contested and ultimately only be relative, not absolute. Indeed, this is a particular problem if one tries to establish more hierarchical, absolutist structures because such structures do not have sufficient flexibility to adapt to change, challenge and contestation. Pluralist structures, in contrast, often represent 'a hybrid between hierarchical and network forms of order' ${ }^{76}$ As Krisch argues, such a hybrid 'allows for regimes with an internally hierarchical structure, but denies them ultimate supremacy, and thus navigates between routine hierarchies

76 Krisch 2010, above n 14, 239. 
and exceptional disruptions, to be solved eventually only through consensual forms'. Thus, perhaps counter-intuitively, the flexibility inherent in pluralist structures can be a source of stability because tensions in the social order have space to play out in the legal governance structure itself. Pluralism provides openings for multiple actors and multiple voices and thus offers safety valves that more hierarchically-based institutions typically lack. As such, we may find pluralist structures to be more stable than hierarchical ones over time. ${ }^{77}$

As to democracy, some maintain that only territorially defined nationstate communities can legitimately claim to exercise democratically grounded power. But such a statement assumes much of what global legal pluralism seeks to challenge, and it is far from clear that the imperatives of democratic sovereignty necessarily render any consideration of transnational, international or non-state jurisdictional assertions illegitimate. First, it is no threat to sovereignty for a nation-state to decide that its sovereign interests are advanced overall by deciding to defer to norms or decisions of other institutions (whether state-based or not) that limit what it can otherwise do. Second, some non-state norms (such as international human rights norms) may actually strengthen domestic democracy, properly understood. This is because constitutional democracy already includes within it the idea that 'all people (and not merely the majority) can associate themselves with the project of selfgovernment' ${ }^{78}$ Thus, obedience either to non-state norms that minimally protect minority interests or to multilateral institutions that help guard against capture of government by minority factions actually enhances democracy rather than subverts it. ${ }^{79}$ Third, at least when non-state norms influence or are formally incorporated into domestic law, such incorporation often occurs through the actions of domestic political actors on either the national or local level, ${ }^{80}$ and it is unclear how there could be democracy objections to such influence. Finally, and most fundamentally,

77 Halberstam 2012, above n 48.

78 CL Eisgruber, Constitutional Self-Government (Cambridge MA, Harvard University Press, 2002) 19.

79 R Dworkin, Freedom's Law: The Moral Reading of the American Constitution (Cambridge MA, Harvard University Press, 1996); RO Keohane, S Macedo and A Moravcsik, 'Democracy-Enhancing Multilateralism' (2009) 63 International Organisations 1; J Mayerfeld, 'The Democratic Legitimacy of International Human Rights Law' (2009) 19 Indiana International and Comparative Law Review 49.

80 J Resnik, 'Foreign as Domestic Affairs: Rethinking Horizontal Federalism and Foreign Affairs Preemption in Light of Translocal Internationalism' (2007) 57 Emory Law Journal 31. 
legal norms have always migrated across territorial boundaries, and precepts that come to be thought of as constitutive of a community can often be traced historically to ideas borrowed from other sources outside that community. ${ }^{81}$ 'Ideas, norms, and practices do not stop at the lines people draw across land, ${ }^{\prime 2}$ and non-state norms are always translated into local vernacular. ${ }^{83}$ This process of 'vernacularization' and the debate about ideas, norms, and practices that go along with it are and always have been part of democratic discourse, not in opposition to it. As Seyla Benhabib has argued,

The spread of cosmopolitan norms ... has yielded a ... political condition [in which] the local, the national and the global are all imbricated in one another. Future democratic iterations will make their interconnections and interdependence deeper and wider. Rather than seeing this situation as undermining democratic sovereignty, we can view it as promising the emergence of new political configurations and new forms of agency $\ldots .{ }^{84}$

In short, pluralist structures provide multiple ports of entry and multiple opportunities for contestation. Such forms of contestation and counterdemocracy sit alongside typical electoral processes and may be seen to be part of the character of a multi-dimensional democratic system. As Krisch points out, '[e]lections will probably remain central to any conceptualization of democracy, but some of the weight they carry domestically might, in the postnational sphere, be borne by other, contestatory mechanisms'. ${ }^{85}$

These are not complete answers, of course, either to the challenge about certainty or the challenge about democracy. But they do indicate that global legal pluralism does have a range of possible responses to those challenges. Further research will be needed to empirically evaluate the force of these challenges in a variety of factual settings and to further build philosophical underpinnings for pluralism that respond to these concerns.

81 Eg, J Resnik, 'The Internationalism of American Federalism: Missouri and Holland' (2008) 73 Missouri Law Review 1105.

82 J Resnik, J Civin and J Frueh, 'Ratifying Kyoto at the Local Level: Sovereigntism, Federalism, and Translocal Organizations of Government Actors (TOGAS)' (2008) 50 Arizona Law Review 709.

83 SE Merry, Human Rights and Gender Violence: Translating International Law into Local Justice (Chicago, University of Chicago Press, 2006).

84 S Benhabib, Another Cosmopolitanism (Oxford, Oxford University Press, 2008).

85 Krisch 2010, above n 14, 271. 


\section{GLOBAL LEGAL PLURALISM AND 'CLASSIC' LEGAL PLURALISM}

As noted at the outset, global legal pluralism builds upon earlier scholarship focused on legal pluralism in more localized settings. Scholars such as Sally Falk Moore, Leopold Pospisil, Franz and Keebet von Benda Beckmann, Marc Galanter, John Griffiths and Sally Merry turned to legal pluralism as a critique of liberal legality. And, true to this political agenda, these scholars were sceptical about the hegemonic impact caused by the framing discourse of law itself. They fought against a de-historicized, hierarchical vision of law that allowed the takeover of the legal field by state institutions. And they were thus acutely aware that legal pluralism was a radical challenge to the presumed power of official state systems.

Accordingly, one potential concern about global legal pluralism and constitutional pluralism as they have evolved in their various incarnations is that they have lost this edge of radical critique. Global legal pluralism and constitutional pluralism, in an attempt to be more practically useful, are perhaps less self-suspicious about the hegemony of liberal legal discourse, procedures, and institutions, and they therefore tend to fall back on such liberal legality in pursuing their normative programmes.

This argument is a useful one, and I think it is correct as far as it goes. But that only means that the evolution of global legal pluralism is on a different trajectory from the original legal pluralists. Indeed, the context and aims of global legal pluralism and constitutional pluralism are very different from those of classic legal pluralism. Importantly, the classic legal pluralists were principally engaged in critique of a dominant view of legality, and they were pursuing this critique primarily from the perspective of thicker description. It is no accident that many of the original legal pluralists were social scientists, not law professors or legal philosophers. And while these authors did likely have a normative sympathy for counter-hegemonic legalities, such normative commitments were generally unstated and implicit.

In contrast, constitutional pluralists and many global legal pluralists are actually trying to advocate a plausible set of institutional arrangements and procedural mechanisms in order to make dominant legal and governmental entities more pluralist in orientation. That is a very different starting point, and it is therefore not surprising that these scholars do indeed tend to embrace aspects of liberal legality as a given. Thus, it is undoubtedly true that the new generation of global legal pluralists has not severed ties with classic state-based legal theory (and 
its limits), but it is also true that this new generation is no longer aiming to completely sever such ties in the name of radical critique; it is instead trying to introduce more pluralist frameworks into hegemonic structures to make them more accommodating to hybridity. And that means there will be limitations on the range of hybridity, the language used, and the sorts of arguments entertained. But, these scholars would argue, the result is still better than if no pluralism had been introduced into the framework at all.

Some may not agree. They may say that it's not a truly pluralist vision unless it goes all the way and rejects (or at least challenges) the discourse of law itself. It is fine to make that argument. But I think such critics should at least also acknowledge that such a position makes it difficult to put forward a practical programme with a chance of being implemented in a still largely state-based world. Accordingly, the less radical nature of constitutional pluralism or global legal pluralism is not an unself-conscious adoption of hegemonic frameworks, but a conscious choice to participate in a discourse about institutional design that would not be available without at least adopting certain assumptions and conventions.

Does this evolution mean that global legal pluralism is not truly pluralism at all? Certainly the new variants of legal pluralism are less oppositional and are willing to countenance liberal legal hegemony even while seeking to open more space for alternative voices within the framework. And it is likewise fair and appropriate to criticize these approaches for precisely that choice. But I think it is unduly doctrinaire and closed-minded to say that such approaches cannot rightly call themselves pluralist or draw on an earlier tradition, even if that tradition was somewhat different in its focus. The nature of scholarly threads is that an idea put forth in one context and with one aim can be appropriated and developed in another context for slightly different purposes. And of all people pluralists should understand that.

We can perhaps criticize global legal pluralism or constitutional pluralism for not being sufficiently counter-hegemonic, but as we do so, we need to first acknowledge that both the goals and the institutional role of the new pluralists are fundamentally different from the old, and so we should not be surprised that the resulting scholarship is also different, both in tone and in content. Second, we need to recognize that at least some of these pluralists are keenly aware that, as noted previously, the pluralist vision is often consistent with liberalism even though it is a structurally different framework; there is no lack of self-consciousness or self-suspicion in that. And, third, we must understand that whether or not a scholar is an 'heir' to an earlier strand of scholarship is not for a purist 
gatekeeper to regulate; ideas morph in plural ways, and the recent moves to constitutional and global legal pluralism are just a few of the many plural variants of pluralism, which is as it should be.

\section{CONCLUSION}

The evolution of global legal pluralism scholarship is astonishing in its variety, richness, empirical detail, and theoretical sophistication. Indeed, this survey merely scratches the surface of the burgeoning literature in the field. And, over the coming decades, we can expect this scholarly framework to develop further, putting forth new models for conceptualizing interactions among relative, non-hierarchically organized legal orders, identifying new mechanisms, institutions and practices for structuring such interactions, and evaluating the strengths and weaknesses of the regimes that emerge. This literature, taken as a whole, will continue to offer a distinct and powerful ongoing challenge to the more formalist models of classic international relations and international legal theory. 